\title{
“ 停课不停学”形势下提高高一英语线上教学的有效性的策略研究
}

\author{
贾艳青 \\ 山西省原平市范亭中学 \\ D O I:10.32629/jief.v2i1.478
}

[摘 要] 目前, 由于受新型冠状病毒的影响, 我国各地纷纷采取延期开学的策略。山西省教育局一方面利用官方网络开展健康教育, 宣传普 及疫情防控知识, 促进学生身心健康发展, 另一方面也积极号召各地严格按照规定开展符合要求的线上教学。初中英语就像一个小水塘, 一 眼就看到边界; 而高中英语就像汪洋大海, 无边无际。高一英语是高中三年英语学习的重要起点, 也是初中英语向高中英语过渡的转折点, 因此，高一英语线上教学也至关重要。本文旨在对“停课不停学”形势下，提高高一英语线上教学的有效性的策略进行探讨。

[关键词] 高一英语 ““停课不停学”; 线上教学 ; 有效策略

教育是一个国家的立国之本，也是一个民族长盛不衰的重要基石。 高一英语是高中三年英语学习的重要起点,也是初中英语向高中英语过渡 的转折点。由于肺炎疫情比较严重, 教育部已经要求延迟开学, 实现 “停 课不停学”。我校高一年级也积极开展了符合规定的线上英语教学。

\section{1 我校当前高一英语线上教学存在的主要问题}

2 月 17 日, 随着国家中小学网络云平台正式启用, 全国绝大部分中 小学生都开始了新冠肺炎疫情下的特殊学习。我校高一年级也积极开展了 符合规定的线上教学, 但通过高一年级各班英语老师网上发放问卷, 分析 问卷结果了解到当前我校高一英语线上教学仍存在一些问题。

1.1 受网络电子设备等客观因素制约较大

高一英语线上学习对教师和学生的网络要求较高。经分析调查问卷 发现, 一些高一年级同学英语学习受网络电子设备等客观因素制约较大。 高一英语线上学习需要学生教师都具有较稳定的网络系统和网络设备。而 我校大部分学生均来自于农村地区, 学生家庭条件一般, 家庭网络环境较 差。在上课过程中有部分学生由于突然停电、网络较差、手机运行较慢等 原因不能按时完成学习任务。

1.2 学生自主学习能力较差, 学习自觉性较低

高一英语线上教学对学生的自主学习能力有较高要求, 同时也是对 学生的学习自觉性的考验。按照我校安排, 在 “停课不停学” 期间, 每周 一至周五安排一节时长为 40 分钟的英语课, 这就需要学生自觉认真完成 老师每天安排的任务, 并对下节课做好充分预习。而在实际教学过程中发 现, 由于学生学习自觉性较差和其他原因, 部分同学不能够准时上课, 有 些同学听课时间不够, 也有同学上线挂机不听课。同时, 网络的不规范也 使部分自觉性较差的学生身心受到威胁, 部分学生假借上网课之名而沉迷 于网络游戏, 严重影响英语学习效率。

1.3 师生间、同学之间的情感交流不畅通。

在日常学习过程中, 高一英语教师可以根据学生的表情或者动作来 判断学生的想法, 更好的进行下面一步沟通或者教学内容的调整。而在进 行线上教学过程中, 师生之间的互动交流较少。有时学生提出问题, 老师 由于种种原因不能及时给予答复或是答复不明确, 学生还是不能理解, 常 会造成学生对老师产生误会, 毕竟文字上的交流不如语言交流来得畅快。 同学间的交流更加缺少, 有的时候一年学习下来互相不认识, 也让很多学 生感到遗憾。

2 提高高一英语线上教学的有效性的主要措施

在 “停课不停学” 形势下, 提高高一英语线上教学的有效性需要坚 持学生主体地位与教师主导地位相结合的原则; 需要注重个性化教学; 需 要构建合理完善的家校联合体系。

2.1 坚持学生主体地位与教师主导地位相结合的原则

在 “停课不停学” 形势下, 提高高一英语线上教学的有效性需要坚 持学生主体地位与教师主导地位相结合的原则。在高一英语线上教学过程 中, 英语教师要尊重学生的主体地位, 要从高一学生英语学习的实际出发, 线上教学时英语教师注意有意识放慢语速, 放慢讲课节奏, 减少课堂容量, 充分考虑到高一年级学生的英语学习程度, 上课给学生充分反应、记笔记 和理解时间。要把教师作为引导者的作用和把学生作为学习主人的地位两 者紧密结合起来。如果高一英语教师只关注于无限扩大网络课堂教学的容
量, 反而会加重高一学生的英语学习负担, 打消高一学生英语线上学习的 积极性。同时, 在高一英语线上教学过程中, 高一英语教师需要采取适当 教学措施的外界干预, 帮助学生提高上课注意力, 比如上课语言风趣幽默、 加强上课师生互动、课后检查笔记等。80\%的学生都是视觉性学习类型, 上课看着老师有利于自己注意力保持和学习效果, 所以用电脑课件直播教 师打开头像上课。

\section{2 要注重个性化教学}

在 “停课不停学” 形势下, 提高高一英语线上教学的有效性需要注重个 性化教学。当前我校高一学生的英语学习学习成绩参差不齐, 一些高一学生 对于英语学习的热情较低, 而且在英语学习中集中注意力的时间也相对较短。 因此, 在高一英语线上教学过程中, 高一英语教师要利用信息化教学技术教 学, 在高一英语课件中准备多样化的教学内容, 比如在每天上课前播放部分 英语歌曲、英语电影等, 来刺激学生的英语学习内驱力, 提高高一学生英语 线上学习的积极性。同时, 高一英语教师在教学过程中也可以注重个性化教 学, 提出一些发散性问题来让学生讨论。例如, 在高一英语必修三 Module3 The Violence of Nature 中, 不同的学生可能听说过不同的自然事件, 英语教师 就可以坚持个性化教学的原则, 针对自然灾害提出一些发散性的问题, Have you ever read a news story about a thunderstorm, a flood, or a hurricane? Can you describe it? 同学们就会根据问题在评论框中展开交 流分享, 学生英语线上学习的积极性也会不断增强。

2.3 要构建合理完善的家校联合体系

在 “停课不停学” 形势下, 提高高一英语线上教学的有效性需要构 建合理完善的家校联合体系。家庭是学生成长的港湾, 家庭教育是学校教 育的基础, 是与学校教育互为补充的重要教育途径。在 “停课不停学” 形 势下, 需要加强家长和老师之间的联系, 使家校合一。在防疫期间, 如果 家长有时间、有条件建议尽可能陪同学生听课, 提高学生的英语听课专注 度和效率。“家庭就是学校, 居家就是课堂, 家长就是班主任”。全体家长 要积极配合学校, 督促孩子及时进行背诵, 认真完成作业, 及时向英语老 师汇报英语学习情况, 力争做优秀监护人, 做好孩子居家防疫和线上学习 的督促检查工作, 给孩子创造一个安全、温馨、充满关爱的生活环境。各 位学生要按照学校及老师的安排, 做到离校不停学, 学习不延期, 成绩不 滑坡, 实现弯道超车。

由于肺炎疫情比较严重, 教育部已经要求延迟开学, 实现 “停课不 停学”。在 “停课不停学” 形势下, 提高高一英语线上教学的有效性需要 坚持学生主体地位与教师主导地位相结合的原则; 需要注重个性化教学; 需要构建合理完善的家校联合体系。

[参考文献]

[1]孙淑梅. 基于混合式教学的大学英语视听说教学改革 [J].当代教 育实践与教学研究,2020(04):33 34.

[2]杨海霞. 高职英语线上线下混合式教学模式方案的设计与实施分 析 [J].海外英语,2020(02):272- 273.

[3] 肖骅. 高职英语教学中混合式教学的应用分析 [J]. 国际公 关,2020(01):118.

作者简介: 贾艳青(1996), 女, 汉族, 山西原平人, 本科, 研 究方向 : 班主任工作, 英语教学, 从事工作 : 教师。 